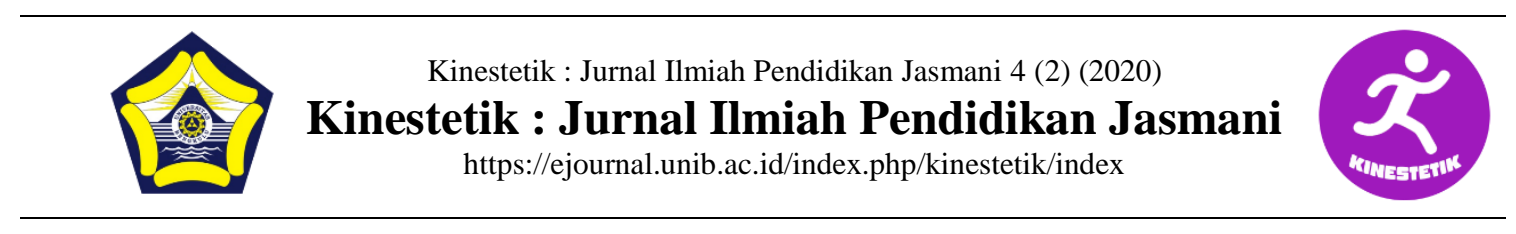

\title{
EVALUATION OF THE PHYSICAL TRAINING PROGRAM OF THE BADMINTON ACHIEVEMENT CLUB IN BENGKULU CITY
}

\author{
Bogy Restu Ilahi ${ }^{1}$, Hadiwinarto $^{2}$, Sheren Dwi Oktaria ${ }^{3}$ \\ ${ }^{123}$ Postgraduate, FKIP, Universitas Bengkulu, Bengkulu, Indonesia
}

\begin{tabular}{l}
\hline Article Info \\
\hline Article History: \\
Received September 2020 \\
Revised September 2020 \\
Accepted September 2020 \\
Available online September 2020 \\
Keywords: \\
Program evaluation, physical \\
training, badminton coaching \\
club \\
\hline
\end{tabular}

\begin{abstract}
The purpose of this study was to evaluate the badminton club performance coaching physical training program. This research was conducted at the badminton coaching club Bengkulu city in 2021. In this study using the CIPP Model with survey research methods. Data obtained through observation, questionnaires, interviews, and documentation study. This study uses non-statistical qualitative analysis methods, where the data reduction component and data presentation are carried out simultaneously with the data collection process after being collected, so that the three components are analyzed (data reduction, data presentation, drawing conclusions) interact. The results of this study indicate that (1) the process of the eligibility mechanism and the qualifications of coaches and badminton achievement coaching club athletes in Bengkulu City includes PB. Orchid, PB. Porpu, PB. Tupperware is quite decent. (2) The implementation of the physical exercise program has not been going well, in the trainer and athlete sectors. (3) The facilities and infrastructure owned by the badminton achievement coaching club in Bengkulu City are still in the poor category because only PB. Porpu have adjusted the facilities and infrastructure according to PBSI standards while PB. Anggrek and PB.Tupperware still need to be fixed.
\end{abstract}

Corresponding address : Jl. Student Alley no. 37 Dusun 3 Nakau Bengkulu
Tengah
Email $\quad$ bogyrestu@unib.ac.id




\section{INTRODUCTION}

Achievement of peak achievements in sports can only be achieved through a systematic, planned, orderly and continuous coaching program process. Therefore, a comprehensive achievement in a tiered pattern of formation. In this case, the achievement of national sports peak achievements is pursued through a national sports coaching pattern that refers to the pyramid system. "The pyramid system in question includes installation, breeding, development of achievement to achieve peak performance".

A systematic, planned, regular and continuous coaching process needs an evaluation because a field of work can be done good or bad if an evaluation has been carried out. Suchmanin Arikunto views "evaluation as a process of determining the results achieved by several activities planned to support the achievement of goals". Conducting an evaluation of the training program, the facts of the implementation in the field will be found with the results being either positive or negative. An evaluation carried out in a professional manner will produce objective findings, namely findings as they are; both the data, analysis and conclusions are not manipulated which will ultimately provide benefits.

One of the organizing the coaching process is a club that is under branch management (Pengcab). In the process of coaching towards the highest possible achievement, sports associations (clubs) are in a strategic place, because they are in the forefront and become the spearhead of achievement development.
Sports clubs are one of the most important coaching institutions or organizations to carry out performance development tasks. The club is a forum for gathering athletes, both young and senior. The club is where coaches, coaches develop and implement their training knowledge.

In Bengkulu City itself, many badminton clubs have been established, but only a few clubs have provided performance development from an early age, youth to adulthood among them. The club that will be the author's research site is PB. Porpu, PB. Tupperware, PB. Orchids in Bengkulu City.

Bengkulu badminton athletes are only biased as a complement in the match, not as a finalist during the semifinals or finals in the match and are always tired which results in pain after going through the preliminary rounds considering the time span of the match is always close and tight during the group phase. All are clarified by the PreResearch which researchers with direct interviews to PB head coaches. Porpu Bengkulu City who also serves as a companion coach of the PBSI Badminton Contingent Bengkulu City national dieven, Mr. Ramdan.

Mr. Ramdani explained that the main factor that causes the Bengkulu Contingent to always fail in national prestigious events is due to physical fitness problems because the time span of the matches is very tight, causing athletes to only be able to penetrate the preliminary round and fail to enter the next phase. Because badminton is a competitive sport, which requires physical readiness, which is mainly followed by technique, tactics, mentality and champion maturity. 
From some of the statements above, it can be concluded that a physical training program is a primary need for a badminton sport of course because if a physical training program is neglected, the sport will not have guidelines and ultimately the goal is difficult to achieve. Therefore, a physical exercise program should be carried out systematically, have a clear reference basis and careful planning. Apart from these aspects, the thing that must be done after carrying out the activity is evaluation.

Problem focus

\section{a) Context}

-The basis for the implementation of stake holders is the physical training program for badminton achievement coaching clubs in Bengkulu City.

-Stakeholders' views and understanding of the badminton achievement coaching club physical training program in Bengkulu City.

-The objectives of the physical training program activities and their relevance to regional and national badminton needs.

b) Input

- Availability of planning for a badminton achievement coaching club physical training program in Bengkulu City.

- Availability of qualified coaches to support the physical training program for badminton achievement coaching clubs in Bengkulu City.

- Quality of players involved in the physical training program of badminton achievement coaching clubs in Bengkulu City.
- Availability of adequate facilities and infrastructure in order to support physical training program for badminton achievement coaching club in Bengkulu City.

- Management and organization support in preparing a badminton performance coaching club physical training program in Bengkulu City.

\section{c) Process}

-Written preparation for the implementation of the physical training program for the badminton achievement coaching club in Bengkulu City

-The implementation of a physical training program which consists of physical components, namely endurance, strength, flexibility, speed, coordination, power according to established guidelines.

-Supervision of the physical training program for badminton achievement coaching clubs in Bengkulu City.

\section{d)Product}

-Achievement of the quality and quantity of players after participating in the badminton performance coaching club's physical training program in Bengkulu City.

-Improved physical condition of players after participating in the badminton achievement coaching club physical training program in Bengkulu City.

Theoretical study

The definition of evaluation according to Arikunto and Cepi views evaluation as "a process of determining the results that have been achieved by several activities planned to support the achievement of objectives". Winarno defines that "evaluation is a systematic process to determine value based on data 
collected through measurement". Meanwhile, Widoyoko defines that "evaluation is a process or activity of selecting, collecting, analyzing and presenting information that can be used as a basis for decision making and further programming". From some of the opinions above, it can be concluded that evaluation is an effort to determine value based on data obtained from measurement results in order to provide information to be conveyed to decision making about the effectiveness of the program that is being or has been carried out.

\section{METHOD}

In this study usingThe CIPP model is in principle consistent with program evaluations aimed at making alternative decisions and following up on issues of a decision. This research data is in the form of written or spoken words, pictures, photos, or actions obtained from data sources, namely: coaches, coaches, athletes, documents. Some of the data collection techniques used are as follows:

\section{Observation (Observation)}

Observation is direct observation,

in this case to find out the factual conditions, namely the coaches or administrators, coaches, athletes, and supporting facilities and infrastructure in improving badminton achievement in Bengkulu City.

\section{Questionnaire}

The questionnaire is a number of written questions that are used to obtain information from respondents about something being researched. The use of this questionnaire is used because it is considered more effective and efficient besides that it also makes it easier to analyze data. In this case, to find out perceptions or opinions in the badminton physical training program.
3. Interview

In this study using an unstructured interview type. This is done to gather as much information as possible from the informants. Interviews were aimed at coaches and several athletes.

\section{Documentation Studies}

Documentation is carried out with the aim of obtaining data in the form of written data, photographs and images for the purpose of validating research data. A large amount of data and facts are stored in material in the form of documentation, the main characteristic of this data is not limited to space and time so that it provides opportunities for researchers to find out about things that have happened in the past.

For data analysis using nonstatistical qualitative analysis methods, where the data reduction component and data presentation are carried out simultaneously with the data collection process after being collected, the three components are analyzed (data reduction, data presentation, drawing conclusions) interact.

\section{RESEARCH RESULT Discussion}

The badminton achievement coaching club in Bengkulu City is a place that is shaded by badminton athletes from an early age to adulthood consisting of various clubs, namely $\mathrm{PB}$. Orchid, PB. Porpu, PB. Tupperware.

The training in all badminton achievement coaching clubs is carried out for all levels, both early age, teenagers, cadets and adults with a duration of 4 times a week to 6 times a week depending on the respective club They practice after school with a duration of 2-3 hours at a time, with continued games in the field 
and outside the field. Most important when club physical training is only PB. Porpu which had sufficient quality of training led to central PBSI followed by PB. PBSI still hopes for orchids and tupperware.

Fund for coaching an achievement coaching club in Bengkulu City which consists of PB. Orchid, PB. Porpu, PB. Pure tupperware comes from athletes' monthly contributions which are calculated only in the range of 100-150 thousand per month with a relatively dense number of exercises 4-6 x a week without the slightest help from the PBSI regional administrators who completely delegate coaching to the club by eliminating Pelatda so that supporting infrastructure The physical exercise program is very difficult to materialize without the assistance of the PBSI supervisor or regional administrator which results in very minimal suitability and feasibility of infrastructure. Regarding the insights of the stake holders of the achievement development club in Bengkulu, including coaches, coaches and athletes, they still need good improvements such as training, seminars, upgrading and others so that the training program is mandatory.

\section{CONCLUSION}

Based on a discussion of the performance coaching club physical training program in Bengkulu City, it can be concluded, namely:

1) The basis for the implementation of stake holders is the physical training program for badminton achievement coaching clubs in Bengkulu City, which consists of PB. Orchid, PB. Porpu, PB. Tupperware already has enough groundwork although it still needs attention.
2) Stakeholders' views and understanding of the badminton achievement coaching club physical training program in Bengkulu Cityconsists of PB. Orchid, PB. Porpu, PB. Tupperware only PB. Porpu, which has been categorized as good, still needs significant improvement.

3) The objectives of the physical training program and its relevance to regional and national badminton needs can be seen from the achievements of the respective clubs which have given rise to regional level achievements but none at all.

\section{a. Input}

1) The availability of planning for the physical training program for the badminton achievement coaching club in Bengkulu City already exists but all club plans are not in accordance with what was seen on the field when the implementation of the physical training program took place.

2) The availability of qualified trainers to support the physical training program in Bengkulu City is only PB. The good Porpu adjusts the PBSI guidelines while the PB. Orchids and PB. Tupperware still needs attention.

3) The quality of the players involved in the physical training program of the badminton achievement coaching club in Bengkulu City is quite good, seeing that from the achievements so far there has been a different level division for each athlete.

4) The availability of adequate facilities and infrastructure in order to support the physical training program of the badminton achievement coaching club in Bengkulu City is only PB. Porpu 
which is classified as quite good even though it has not adjusted the PBSI guidelines, while PB. Orchids are still lacking and PB. Tupperware has absolutely no infrastructure to support a physical exercise program.

5) The support of the management and organization in preparing the physical training program for the badminton achievement coaching club in Bengkulu City for club coaches is very minimal, while the PBSI regional administrator only leaves completely to the club without any assistance.

\section{b. Process}

1) Preparation for the implementation of the physical training program for badminton achievement coaching clubs in Bengkulu City in writing, both short, medium and long term plans are only PB. Its Porpu but the PB club. Orchids and PB. Tupperware does not exist at all.

2) The implementation of the physical training program which consists of physical components, namely endurance, strength, flexibility, speed, coordination, power according to the established guidelines, all badminton achievement coaching clubs in Bengkulu City have been good even though they have not fully implemented them.

3) Supervision of the physical training program of the badminton achievement coaching club in Bengkulu City is good, even though it is a good coach, coaches still have to be given an understanding of the importance of a physical training program.

\section{c. Product}

1) The achievement of the quality and quantity of players after participating in the physical training program of the badminton achievement coaching club in Bengkulu City is sufficient to be at the regional level, it can be seen from the achievements and results of the evaluation data of each coach but needs to be addressed to compete in the national arena.

2) The improvement in the physical condition of the players after participating in the badminton performance coaching club physical training program in Bengkulu City was only PB. Porpu is already good, it can be seen clearly from the evaluation data of the athlete's three-month physical condition, while PB. Orchids and PB. Tupperware does not exist at all.

\section{RECOMMENDATION}

Based on the results of this study regarding the physical training program for achievement coaching clubs in Bengkulu City, several recommendations can be put forward, namely:

1) Providing input to policy makers in all achievement coaching clubs to continue to support the sustainability of the physical exercise program and to better understand the understanding of the physical exercise program which continues to be updated through seminars, training, refresher courses and others.

2) The model for implementing the PB achievement coaching club physical exercise program Porpu can be used as an example by other badminton 
achievement coaching clubs, especially in Bengkulu City.

3) Referring to the success of the physical training program which is very determined by the supporting facilities and infrastructure of a program so that all clubs must fix their respective facilities and infrastructure without prejudice to the guidelines from PBSI.

4) There is a continuation of the badminton achievement coaching club's physical training program in Bengkulu City. There is a need for a coach who fosters a club with good quality control and supports both material and non-material in order to get maximum performance results.

5) Because the physical training program greatly influences the achievements of the achievement coaching clubs in Bengkulu City, this program needs to be addressed and continued again by optimizing the level of implementation of the physical training program according to the latest PBSI regulations so that it can continue to follow the development of modern badminton.

\section{REFERENCES}

Arikunto, Suharsimi. Prosedur Penelitian Suatu Pendekatan Praktek. Jakarta: Rineka Cipta, 2010.

Arikunto, S \& Cepi, S.A.J. Evaluasi Program Pendidikan.Jakarta: Bumi Aksara, 2008.

Bidang Pembinaan Prestasi. Sistem Pembinaan atlet berprestasi. Jakarta: KONI, 2006.

Bompa Tudor.O Periodization, Theory and Methodology of Training Fifth Edition, h. 86.

Bucher, Chatles. A \&Krote, March. L. Management of Physical Education and Sport. St. Louis, Missouri : Mosby Year Book, inc, 2005.
Depdiknas.Petunjuk Pelaksanaan Pembinaan Dan Pengembangan Klub, Bakat dan Minat Siswa. Jakarta: Depdiknas, 2011.

Dirjen Olahraga. Pedoman Mekanisme Koordinasi Pembinaan Olahraga Kesegaran Jasmani dan Kelembagaan Olahraga Bulutangkis. Jakarta: Depdiknas, 2012.

Farida Yusuf Tayibnapis, Evaluasi Program dan Instrumen Evaluasi. Jakarta: Rineka Cipta, 2008.

Kholison, F., \& Defliyanto, D. (2018). PENGARUH LATIHAN DRILL TERHADAP KEMAMPUAN SERVIS BACKHAND BULUTANGKIS SISWA MTS TARBIYAH ISLAMIYAH KECAMATAN AIR NAPAL BENGKULU UTARA. Kinestetik: Jurnal Ilmiah Pendidikan Jasmani, 2(2), 186-191.

Harsono.Coaching dan Aspek Psikologis dalam Coaching. Jakarta: CV. Tambak Kusuma, 2007.

Harsuki.Perkembangan Olahraga Terkini Kajian Para Pakar.Jakarta : PT. Raja Grafindo Persada, 2008.

James Tangkudung. Kepelatihan Olahraga. Pembinaan Prestasi Olahraga. Jakarta: Cerdas Jaya, 2006.

KEMENPORA.Undang-Undang Republik Indonesia Nomor 3 tahun 2005 Tentang Sistem keolahragaan Nasional.Jakarta: KEMENPORA, 2007.

KONI.Pedoman Pembentukan dan Pembinaan Klub Olahraga .Jakarta: Koni Pusat, 2010.

Marta Dinata, Bulutangkis 2. Jakarta : Cedas Jaya, 2006.

Miles dan Huberman.Terjemahan Tjejep Rohendi Rohidi.Analisis Data Kualitatif.Jakarta: UI Press Buku Asli Terbit, 2005.

Mohammad Rijal, Evaluasi Peningkatan Program Latihan Pemain Pusdiklat Bulutangkis Citraraya Unesa Surabaya. Surabaya: UNESA, 2006.

Sapta Kunta Purnama, Kepelatihan Bulutangkis. Jakarta: Cerdas Jaya, 2010.

Saryono dan Mekar, D.A. Metodologi Penelitian Kualitatif. Yogyakarta: Muha Medika, 2010.

Stark, J.S \& Thomas, A.Assessment And Program Evaluation. Nedham Heights : 
Simon \& Schuster Custom Publishing, 2006.

Siregar, M.F. Pedoman Pembentukan dan Pembinaan Olahraga Prestasi. Jakarta: KONI, 2007.

Sugiyono, Metode Penelitian Kuantitatif, Kualitatif, dan R \& D. Bandung: Alfabeta, 2013.

Sukmadinata, Nana S. Metode Penellitian Pendidikan. Bandung: Remaja Rosdakarya, 2005.

Stufflebeam,D.L. \& Shinkfield. A.J. Systematic Evaluation. Buston: Allyn and Bacon. 2008.

Widoyoko, Eko Putro. Evaluasi dalam Pembelajaran. Jogjakarta: Pustaka Pelajar, 2012.

Winarno, ME. Evaluasi dalam Pendidikan Jasmani dan Olahraga. Jakarta: Center For Human Capacity Development, 2004.

Wirawan. Evaluasi Teori, Model, Standar, Aplikasi dan Program. Depok: Rajagrafindo Persada, 2012. 